\title{
Changes in Holocene Precipitation Pattern of the Central Mediterranean Inferred from Hypogean Tufa Proxy Data
}

\section{Marco Delle Rose*}

National Research Council, Institute of Atmospheric Sciences and Climate, Lecce, Italy

*Corresponding author: Marco Delle Rose, National Research Council, Institute of Atmospheric Sciences and Climate, Lecce, Italy, Tel: +39 0832 298717; E-mail: m.dellerose@le.isac.cnr.it

Received date: Mar 02, 2016; Accepted date: Mar 21, 2016; Published date: Mar 29, 2016

Copyright: (c) 2016 Delle Rose M. This is an open-access article distributed under the terms of the Creative Commons Attribution License, which permits unrestricted use, distribution, and reproduction in any medium, provided the original author and source are credited.

\begin{abstract}
This paper deals with proxies preserved in hypogean tufas of a highly responsive region to climate changes, the central Mediterranean. Field studies allowed determining four stages of carbonate accretion driven by climatic and $/$ or environmental shifts over the mid-late Holocene (i.e., the last eight millennia). The studied accretions show petrological analogies with the so called "trays", particular speleothems reported in few worldwide caves. Positive covariation between the ratios of oxygen and carbon isotopes is interpreted as due to climate signal. Hypogean tufas have recorded a long term (probably millennial-scale) reduction in precipitation and / or shift in storm trajectories as the interlacement of geological and geochemistry features suggests. Local conditions likely became severely dry over the transition from middle to late Holocene. Comparison between tufa archives and regional-scale data may improve climate knowledges and calibration of models. Further researches need interdisciplinary approaches to solve some basic uncertainties and to enhance data on geological archives.
\end{abstract}

Keywords: Isotopes fractionation; Phototropic control; Tray speleothems; Climatic transition; Interdisciplinary earth sciences

\section{Abbreviation}

BS = Bulky Stalactite

\section{Introduction}

The Mediterranean region is highly responsive to climate changes and shows a wide range of weather features [1-3]. Climate signals as mean and extreme precipitation are seasonally dependent even on small distance [4]; spatial and temporal patterns are detected at local scale with opposite trends in adjacent areas [5], and drastic short term meteorological variations affect dry summer areas [6]. Moreover, hydro-climatic variability of Mediterranean during Holocene is still a debated issue [7]. Millennial-scale simulations return a complex pattern of drier, not changed and wetter trends [8]. Again, the assessment of both precipitation and temperature changes over the 21st century shows dramatic differences [9]. To improve our knowledge and to better calibrate the models, regional-scale data have to be compared with geological archives [10-12]. Such a seemingly easy issue hides several difficulties to begin from the epistemological differences among geology and physics. Geology basically is an inductive and probabilistic science [13] thus the intrinsic fuzziness of many geological data is frequently considered as a deficit in comparison with methods and results of the so-called exact sciences. The epistemological core of geology resides in its historical and interpretive nature and its subjects "do not seem to fit well into the conception of a science progressing by the cycle of setting up a hypothesis, testing it by experimentation, verify or falsify it, and continue with a new hypothesis" [14]. Consequently the epistemological dissimilarities between geology and physics imply different pathways of the respective verification processes. If in geology the experimental test results may prove the correctness of the hypotheses, in physics they imply that the hypotheses have "not yet been shown to be false" [15]. Despite this, interdisciplinary work is necessary because our capability to understand climatic variability requires temporal data longer than those based on direct measures $[16,17]$. Stable water isotopes contained in carbonate formations may provide useful key indicators $[10,11]$. However on the practical level, atmospheric modellers need high-quality (low uncertainty) data that unlikely sedimentary proxies preserve. Geologists try to find more reliable climatic records although environmental signals usually are superimposed. Nevertheless, the requirement to deal with materials suitable for precise U-series dating [18-20] restricts the use of the geological data in the models. Especially as regards highly responsive regions as the Mediterranean, the geological records used to improve paleo-climatic models are not again enough to obtain satisfactory simulation. The uncertainties related to the use of isotope ratios recorded by widely distributed lake carbonates constitutes a clear constraint of such a perspective [10,21,22]. The development of an alternative paradigm may enlarge the base of suitable data as well as constitute a new field for scientific debate. As regards carbonate formations like the speleothems, one of the more important archives for paleo-climatic studies, it is common that well dated proxies preserve environmental signals that mask the climatic ones [23]. Especially isotopes fractionation processes may determine ambiguous interpretations $[24,25]$. Thus speleothems precisely U-series dated may have recorded signals of soil and/or aquifer geochemistry processes that strongly alter rainwater isotopic ratios. Knowledge improvement on climate of recent geological ages requires trying alternative paths to enlarge the appropriate records to constrain the models. Attention may be put on sets of climatic proxies on which the environmental noise may be deduced by geological investigations and whose uncertainty on isotope ratios may be statistically assessed by repeated analysis. In such a perspective, clusters of freshwater carbonates can provide suitable data sets. 
This paper deals with carbonate accretions that grew close to the entrances of hypogea and belonging to calcareous tufas [26,27]. In spite of the complexity to obtain reliable radiometric data from such "dirty" accretions due to presence of detrital materials and because they are not closed systems [19] the meaning to combine geochemistry and geological data is stressed in what follows. The case treated here was preliminarily exposed as geological heritage and increases of both carbon and oxygen isotopes ratios (positive covariation), recognized in two series of samples of tufa arranged in stratigraphic succession, were attributed to: (1) a progressive opening of the cave to external conditions, and / or (2) a signal of increase of atmospheric temperature and/or reduction in rainfall [28]. New in situ observations are presented herein to test such hypotheses and to explore the possibilities to improve our understanding of the Holocene climate by studies on calcareous tufas.

\section{Case Study and Method}

Data of the cave growths presented and discussed hereafter come from the Mannute Caves system, a complex of karst hypogea located in the Salento peninsula (South-East Italy, Figure 1) in front of the homonymous bay. The system consists of ten caverns having different size and shape whose entrances open up a very steep cliff between 20 $\mathrm{m}$ and $80 \mathrm{~m}$ above sea level. Hypogea are adorned of dripstones and flowstones up to some tens of accretions for $1 \mathrm{~m}^{2}$ of available surface. Accretions refer to five morphological types and form a continuum of genetically related carbonate fabric ranging from inorganic growths (speleothems) to bio-mediated ones (tufas). Inside the cave named Mannute Piccola $\left(39^{\circ} 48^{\prime} 47,75^{\prime \prime} \mathrm{N} 18^{\circ} 23^{\prime} 06.50^{\prime \prime E}\right.$, Figure 2), the most numerous accretions show elongate shape and oblique axes as result of the control of phototropic processes in their growth. However, the morphological type relevant for the present paper has vertical growth axis and bulbous shapes ("elephant-paw" like). Two core samplings were extracted from a bulky stalactite (BS) and petrographic analysis have revealed alternation of biological and inorganic processes in carbonate deposition. Radiometric analyses have determined the Holocene age although high initial isotopes ratio [230 Th / 232Th] does not enable an accurate chronology [28]. Short geological and climatic features must be given to sketch basic site characteristics. The Salento peninsula has a Mesozoic-Cenozoic basement featured by horst-andgraben setting and karstic cave systems because of the prevalence of calcareous rocks. It is a warm temperate region with hot-dry summer (Csa climate type of Kottek et al. [29], Peel et al. [30]), mild-wet winters and about $650 \mathrm{~mm}$ of average annual rainfall. Local oxygen isotopic composition of present precipitation ranges from -5.0 to -6.0 $\delta 18 \mathrm{O} \%$ [31]. Many cave systems are located along the $35 \mathrm{~km}$ long south-eastern coastal cliff of the Salento peninsula. Some hypogea are popularly known because of the beauty of carbonate accretions adorning their entrances and are destinations of cultural tourism. The Mannute Cave systems can be reached only using rope techniques or watched from the underlying bay. Topographic survey and computer elaboration were performed to a virtual enjoyment of the Mannute Piccola [28] thus the cave was listed in the protected Geological Heritage since 2015.

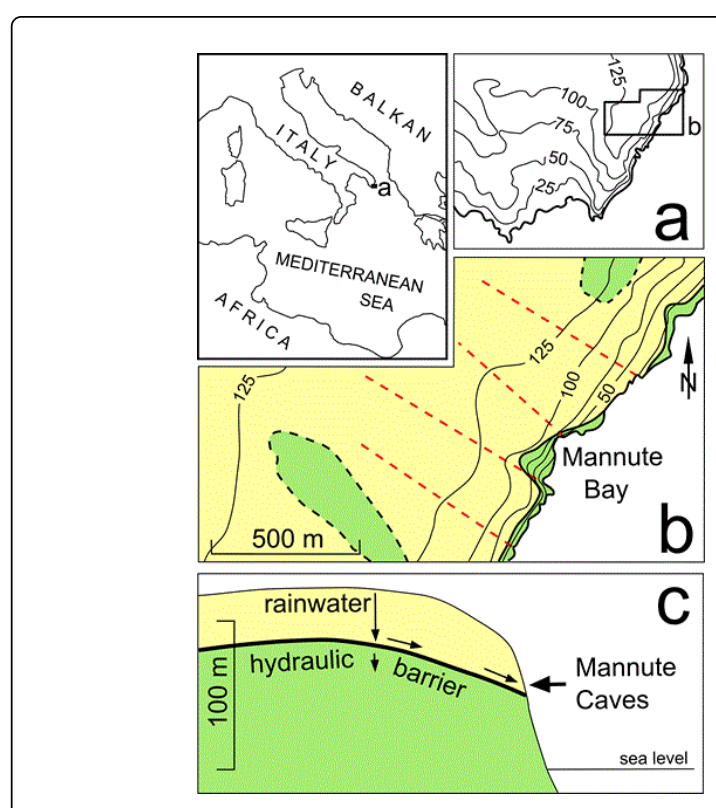

Figure 1: Geographical location; a, contour lines map; b, geological map; c, hydrological scheme; green: pre-Miocene massive limestones; yellow: Miocene clinostratified bio-calcarenites; red dashed lines: main faults.

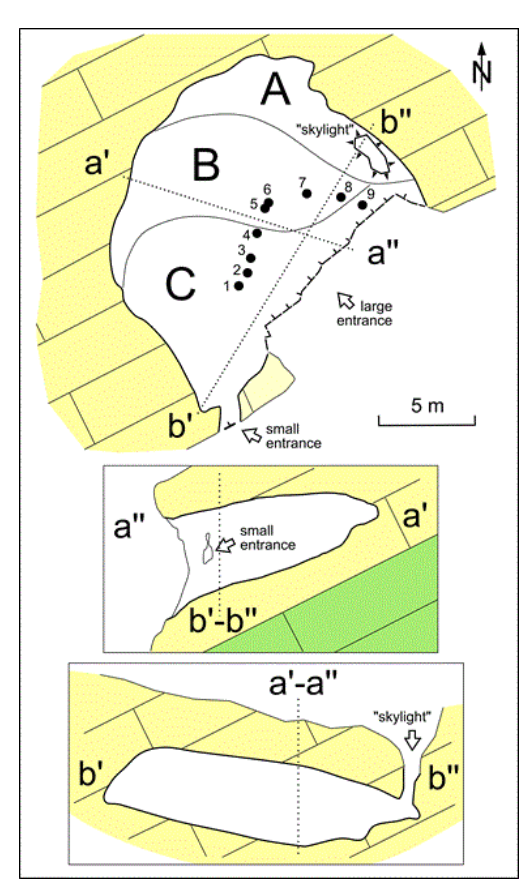

Figure 2: Mannute Piccola cave planimetry and vertical sections.

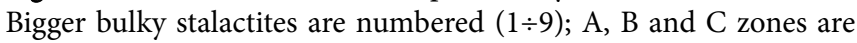
delimited.

To verify the aforementioned hypotheses (see Introduction) concerning the variations of isotope ratios along the cores (Figure 3 ) of BS number 1 of Figure 2, the carbonate accretion processes inside the Mannute Piccola cave were investigated. The first hypothesis entails 
Page 3 of 8

physical changes (temperature, light intensity, wind energy) inside the hypogean due to a progressive enlargement of the main entrance likely caused, in turn, by a series of rock fall events. Thus it does not require climate variation. Differently, the second hypothesis directly implies this latter and the cave would not been subjected to morphological modifications during the bulky stalactites growth. The two different patterns of change involve both the geological and the chemical features of accretions. The insight that has motivated this paper is the possibility to infer the cause of the isotopic variation verifying stratigraphy and morphological properties. The purpose is to document a study-case where a working hypothesis may be verified or falsified by testing analyses. The performed activities inside the Mannute Piccola cave were directed: (1) to detect active or recent carbonate deposition processes; (2) to establish the physical conditions of the BSs growth; (3) to deduce evidences about the chronology of accretions and other carbonate cave products. A field geological survey aimed to state the hydrological features was carried out in the surroundings of the caves system. The in situ investigations concerned: (1) the current dripping water behaviour; (2) the macroscopic processes enabling the accretions growth; (3) the morphometric characteristics of BSs; (4) the accretion stratigraphy of BSs. Traditional terms of cavers are used to describe the geomorphological karst features. Finally, the new data have permitted to better evaluate previous alpha spectrometry U/Th dating.

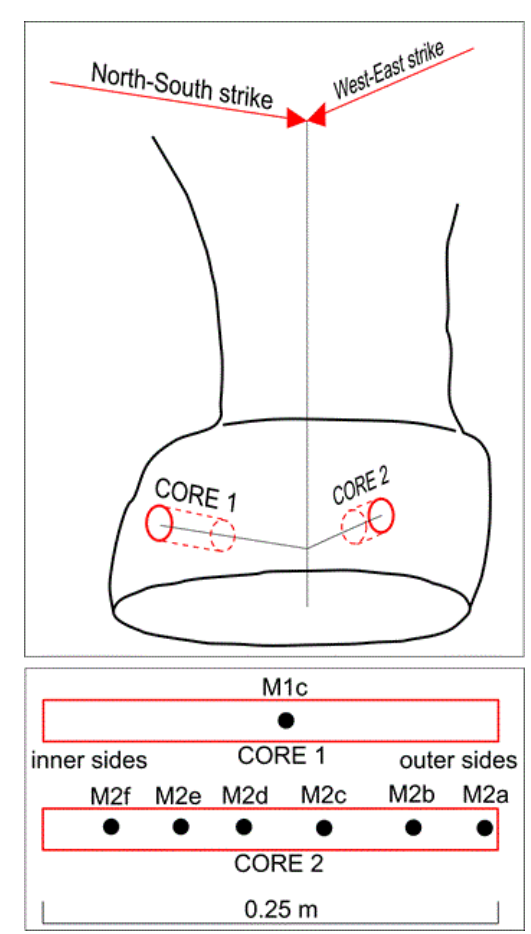

Figure 3: Cores sampling of the bulky stalactite number 1. Samples are alphanumeric indicated.

\section{Geological Outcomes}

The field geological studies allow inferring present and past physical characteristics of the cave site.

\section{Hydrogeological features}

Both stratigraphic and structural features of the studied area control the groundwater circulation. Due to differences in permeability of the rock mass, the seaward sloping angular unconformity between massive limestones and clinostratified bio-calcarenites is the main hydraulic barrier (insert $\mathrm{C}$ of Figure 1). The Mannute Piccola and other caves are located just above such stratigraphic contact thus underlining its control in speleogenesis. Vertical faults and fracture systems oriented NW-SE are other key control factors since they determine the main drainage axes. Infiltrated rainwater directly flows towards the coastal cliff and no aquifer is present above the Mannute Caves. Soils lack along the cliff and form covers whose thickness is up to a few meters on the nearby karst plateau. As observed directly in situ, water dripping inside the hypogea happens just after rain episodes during autumn and winter. As regards the Mannute Piccola cave, dripping occurs especially at the north side (A zone in Figure 2). Taking into account the geological setting, the catchment basin supplying the water dripping extends about $1 \mathrm{~km}^{2}$.

\section{Recent accretion processes}

Three types of recent processes of carbonate formation inside the Mannute Piccola cave have been recognized: (1) bio-mediated accretion due to organic coatings; (2) inorganic growth of dripstones; (3) "moonmilk" deposition. As inferred by morphological features, these processes happened only lately (in geological sense) and perhaps their carbonate products may again be subject to some growth. Several accretions showing elongated shape and oblique axes (erratic stalactites and pseudo-stalagmites described by Delle Rose et al. [28]) have their terminal portions covered by green organic coatings. The biological communities are mainly constituted by macro- and microphytes and allow different biotic carbonate formation processes as well as the trapping of detrital materials (see Discussion). Phototropic communities constitute very thick coasts (up to about 1 $\mathrm{cm}$ ) especially because of clumps of moss. They are mainly found in the B zone of Figure 2. The end surfaces of the BSs are covered by thin (sub-millimetric) bio-films. Processes of physico-chemical (abiotic) carbonate formation related to the current dripping are emphasized by the broad growth of thin cylindrical dripstones (the so called "straws", commonly considered the initial growth stage of the stalactites). Dripping is present also at the tip of more developed stalactites probably without carbonate deposition. Several apparently active cannulas are located within the A zone of the Mannute Piccola (Figure 2). They have taken roots on both the ceiling and pre-existing larger accretions. The third type of recent carbonate accretion processes regards precipitation of aggregates of fine crystals that, as a whole, form white (semi-transparent) "creamy" coats ascribable to the "moonmilk" of the cave explorers. Such thin layers occur within of both A and B zones (Figure 2) where they cover ceiling, walls and floor of the cave as well as BSs, dripstones and flowstones.

\section{Shape observations and morphometry}

The common feature of the BSs is the bulbous shape like the paw of an elephant (Figure 4). However, the flat shape of the ending tip is unusual among the tufas (see Discussion). At a close look, BSs consist of overgrowths (bulbs) covering cylindrical cores (Figure 5). They slightly differ in elevation, the altitudes of the flat bottoms ranging between $39 \mathrm{~m}$ and $38 \mathrm{~m}$ above sea level. Horizontal sections are slightly elliptical (sub-elliptical) rather than circular, the differences between the axes being of a few centimetres. The length of the growth axis and 
the diameter of the horizontal sections (drawn as circular) of nine BSs (numbered 1-9 in Figures 2 and 4) were taken using measuring tape (Figure 5). Morphometric parameters are reported in Table 1. BSs become longer, thinner and slightly sloping from the $\mathrm{C}$ zone to $\mathrm{B}$ zone of the cave. Two of them are coalescent (numbers 5 and 6, see Figure 4) whereas the core of BS number 4 is part of a complex group of accretions.

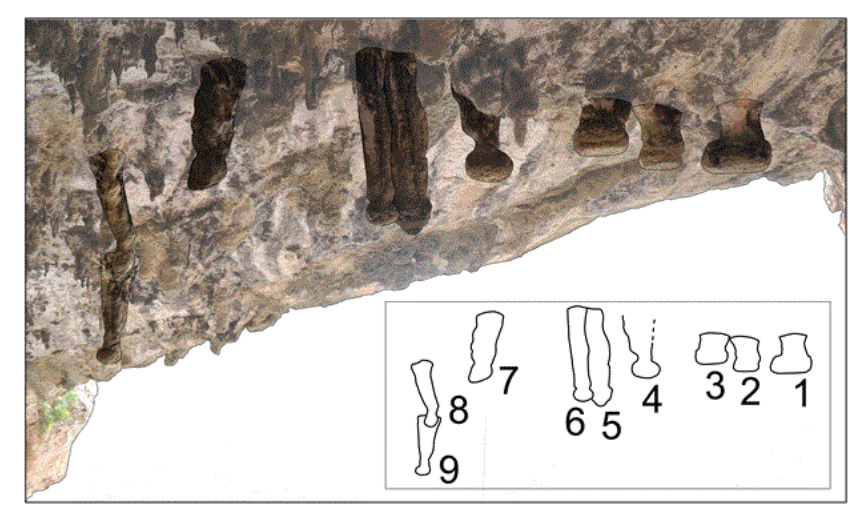

Figure 4: Retouched view of the bulky stalactites hanging from the ceiling of the Mannute Piccola cave.

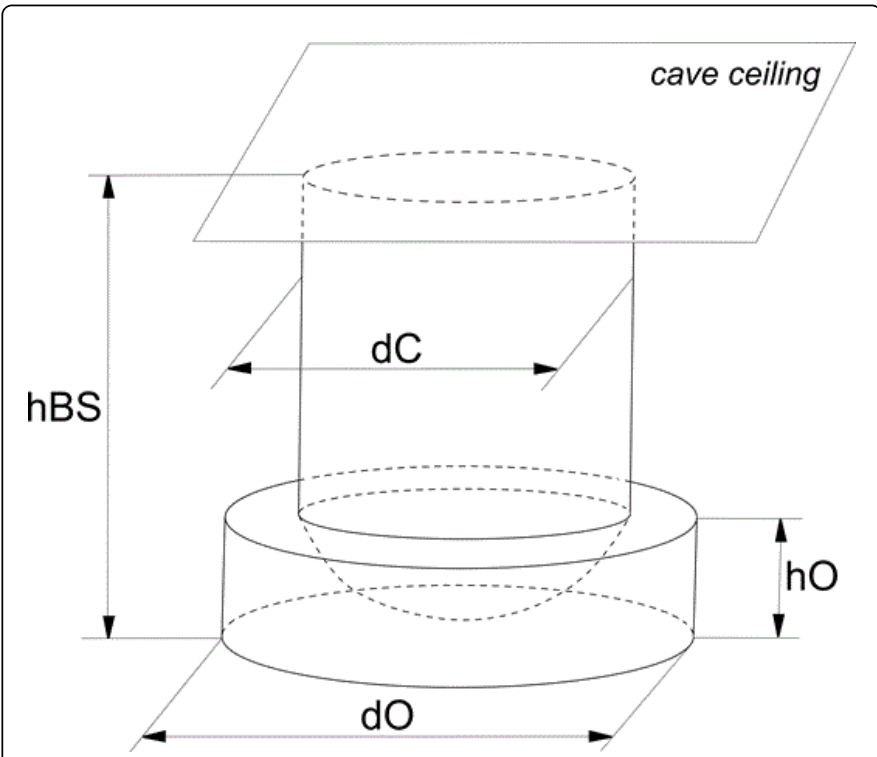

Figure 5: Measured morphometric parameters.

\section{Overgrowth stratigraphy}

In situ observations and extraction of two $25 \mathrm{~cm}$ long sampling cores from the BS number 1 (Figures 2 and 4) allow to determine the internal sedimentary structure of the "elephant-paw" overgrowths. Perforated cores seem to have not reached the cylindrical core of the bulky stalactite (Figure 3). Overgrowth is built up by friable and porous very thin (millimetric) laminas of micrite and crystalline calcite (stromatolitic fabric). The most external part of the bulb (a few centimetres in cores 1 and 2) is hard due to enhanced calcite crystallization. Surfaces of tufas are dressed up by clusters of nodular small masses ascribable to the "sprays of popcorn" of the cave explorers. Popcorn-like crusts cover also portions of the ceiling of the hypogeum and are in turn partially covered by thin (less than $1 \mathrm{~cm}$ ) moonmilk coats. The layers of the above stratigraphy can be related to analogous deposits reported in the speleological literature that have proved to preserve remarkable climate proxies (see Discussion).

\section{Discussion}

Field data help us to understand both the development of the BSs and the causes of the changes in isotopic composition through time.

\section{Bulky stalactites growth}

Both physic-chemical and biological features control the formation of carbonate deposits and produce a great number of morphological shapes as well as petrological fabrics [32]. Carbonate minerals grown in caves show different properties from hard, compact crystalline structure to chalky and highly porous sediments. The former is usually considered mostly inorganic in origin, the latter both inorganic and bio-mediated [33]. Moreover, changes over time of the control factors may determine the development of complex composite accretions. Preliminary morphological observation on the BSs of the Mannute Piccola cave [34] brought to conjecture their affinity with the "phreatic overgrowths" of Fornós et al. [35]. Petrographic analyses proved the attribution to the tufas type and led us to hypothesize the growth in twilight conditions [28] according to the scheme of Taboroši et al. [27]. Data discussed hereafter bring to advance a more complete working hypothesis.

Four stages of carbonate formation were identified by morphological and stratigraphic analyses: (1) cylindrical core stage; (2) tufa overgrowth stage, (3) popcorn clusters stage; (4) moonmilk stage. Unknown are both the type and the time of the cylindrical core growth because of the lack of petrology and radiometric data; thus the framework of the first stage is based on speculative deductions. Inside the Mannute Caves the growth of speleothems occurred not before the late Middle Pleistocene as deducted by the regional geological history [28]. Several accretions formed during this stage occupy the A zone of the Mannute Piccola (Figure 2). Due to the climate of the Upper Pleistocene, a large part of the dripstones probably consists of inorganic stalactites and stalagmites. Their growth would stop during the early Holocene as inferred from overview data [10,25,33]. The development of the cylindrical cores of the BSs may be tentatively ascribed to such a phase of speleothems growth (1-2 in Figure 6). Within the B and C zones of the Mannute Piccola, the growth of the dripstone cores was followed by a tufa overgrowth stage. A warming trend would have driven the replacement of the accretion process. The formation of tufas is strongly precluded by low temperatures $[33,36]$ and thus the "elephant-paw" overgrowths easily began to develop not before the late early Holocene (9 millennia BP). Within warm temperate areas as the Salento peninsula, tufa accretion lasted during the whole mid-Holocene as a result of the long term precipitation trend [37]. Due to the geochemistry and petrography analyses performed on the two extracted core samplings (Figure 3) the overgrowth stage is better documented. Both biological and chemical processes have determined the development of the "elephant paws". Micritic calcite was formed for bio-precipitation due to cyanobacteria. Decaying vegetation was metabolized by microorganisms which precipitated calcium carbonate outer shells as involuntary product. Bio-films trapped both calcareous and non-calcareous detrital materials. Carbonates were probably also produced on diatom stalks, 
within sheaths of bacteria and extracellular polymeric substances $[26,38]$. Actually the true biogenicity of the bio-mediated laminas of tufa is still subject to testing [39]. However, the flat sub-horizontal ending surface of the BSs does not seem to be due to activity of organisms. Tufa accretions grown under twilight conditions show subspherical shapes whereas near the cave entrances their elongate forms reveal strong phototropic growth control [27]. The key process shaping the flat end of the bulbs was probably physical and related to the capillary water in the porous structure of tufas. Taking into account morphological similarities, the hypothesis proposed by Martini [40] to explain the development of the accretions named "trays" is herein considered. In such a view, the passage from stage one to stage two should be due to reduction of dripping that caused, in turn, the formation of carbonate by evaporation at ceiling pendants as the tip of the dripstone cores (2-3 in Figure 6). Considering the differences in morphometry (Table 1) the passage was not synchronous but it happened before in $\mathrm{C}$ zone and later in the $\mathrm{B}$ zone of the cave (Figure 2). Reduced amounts of infiltrated rainwater reached the cave so as to inhibit the dripping but it was enough to allow the presence of films of water on bulbs that - in turn - precipitated crystalline laminas by evaporation. Water moved inside tufa by capillarity and thus the chemical carbonate deposition preferentially occurred upward and lateral so as to determine the flat tray-like end surfaces (3 in Figure 6). Inorganic processes alternated with bio-mediated ones over the second stage and bulbs gradually grew. Light conditions driving the photosynthetic bio-mediation were steadily isotropic as inferred from the regular morphometry of bulbous overgrowths (Table 1) thus the hypothesis of progressive opening of the cave to the external conditions appears unlikely.

\begin{tabular}{|l|l|l|l|l|}
\hline nBS & hBS $(\mathrm{cm})$ & $\mathrm{hO}(\mathrm{cm})$ & $\mathrm{dC}(\mathrm{cm})$ & $\mathrm{dO}(\mathrm{cm})$ \\
\hline 1 & 41.5 & 19.5 & 38 & 50.5 \\
\hline 2 & 38 & 20 & 26 & 29.5 \\
\hline 3 & 35 & 24.5 & 31 & 40.5 \\
\hline 4 & 64.5 & 21 & 18 & 34.5 \\
\hline 5 & 127 & 24.5 & 21.5 & 25 \\
\hline 6 & 123 & 16.5 & 18 & 21.5 \\
\hline 7 & 86 & 23 & 22 & 24.5 \\
\hline 8 & 74 & 15 & 14.5 & 16.5 \\
\hline 9 & 79 & 13 & 15 & 18 \\
\hline
\end{tabular}

Table 1: Morphometric parameters of the bulky stalactites. nBS = Bulky Stalactite Number; hBS = Bulky Stalactite Height; hO = Overgrowth Height; $\mathrm{dC}=$ Core Diameter; $\mathrm{dO}=$ Overgrowth Diameter.

Speculative deductions may be proposed to sketch the timing of stage two. The six samples taken by the core sampling 2 have different degrees of contamination (Table 2). The innermost portion on the BS (samples M2f, M2e, M2d) contains lower amounts of 232Th and U (ppm) than the outermost one. Their 234U / 238U and 230Th / 234Th ratios entered in the diagram of Ivanovich and Harmon [41] is placed along the interval between 8.0 and $4.0 \mathrm{ka}$ (Figure 7). Due to the high amount of detrital thorium (Table 2), the actual age should be lower. However, the crystallization of calcite inside the porous structures of the tufas over the second stage (see above) may have produced an opposite effect on the apparent age [42]. Moreover, the sample M1c extracted from the middle point of the core sampling 1 (Figure 3) results of $4.67 \mathrm{ka} \pm 0.48 \mathrm{ka}$ [15]. Consequently, it can be tentatively assumed that the second stage of the BSs growth stopped at the early late Holocene $(3 \div 4$ millennia BP). Clearly such a hypothesis needs to be verified. It must be noted that a sharp reduction in tufa growth probably affected Europe since $3.5 \mathrm{ka}[26,37]$.

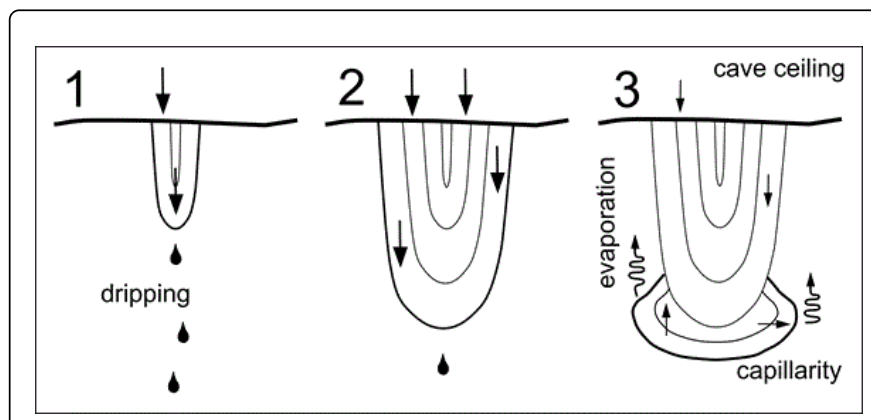

Figure 6: Changes in hydraulic features from stage one $(1,2)$ to stage two (3).

\begin{tabular}{|c|c|c|c|c|c|c|}
\hline & M2f & M2e & M2d & M2c & M2b & M2a \\
\hline $\begin{array}{l}230 \mathrm{Th} \\
234 \mathrm{U}\end{array}$ & 0.071 & 0.055 & 0.037 & 0.039 & 0.167 & 0.066 \\
\hline U (ppm) & 0.557 & 0.508 & 0.653 & 1.251 & 2.241 & 2.630 \\
\hline 232Th & 0.483 & 0.176 & 0.150 & 0.237 & 4.563 & 0.671 \\
\hline $\begin{array}{l}\delta 13 C s \\
\text { (PDB) }\end{array}$ & -4.82 & -5.84 & & -2.34 & & 0.82 \\
\hline $\begin{array}{l}\delta 180 s \\
\text { (PDB) }\end{array}$ & -2.69 & -2.98 & & -1.21 & & 0.65 \\
\hline
\end{tabular}

Table 2: Selected chemical parameters of core sampling 2.

The overgrowth stage was followed by the formation of popcorn-like encrusts without any interruption as stratigraphic features suggest. The hardening of the uppermost portion of the BSs was due to precipitation of calcite within the pores of the more external tufa structures and probably it shortly preceded the formation of the popcorns encrusts. According to the model proposed by Hill [43], the process was favoured by reduction in moisture and / or increase of evaporation inside the cave. However, the collected data do not allow knowing if the cause was climatic (like reduction in precipitation or increase of temperature) or environmental (like enlargement of the cave entrances or increase of wind force). Finally, between the end of the third phase and the beginning of the fourth one there was a sedimentation gap as inferred from the features of the stratigraphic contact between the respective carbonate deposits. During such time interval, the enlargement of the main entrance (Figure 2) and the formation of erratic stalactites and pseudo-stalagmites would happen in order of occurrence [28], thus prolonging the duration of the hiatus. The formation of the moon milk should have occurred under cold conditions as suggested in the literature [33]. 


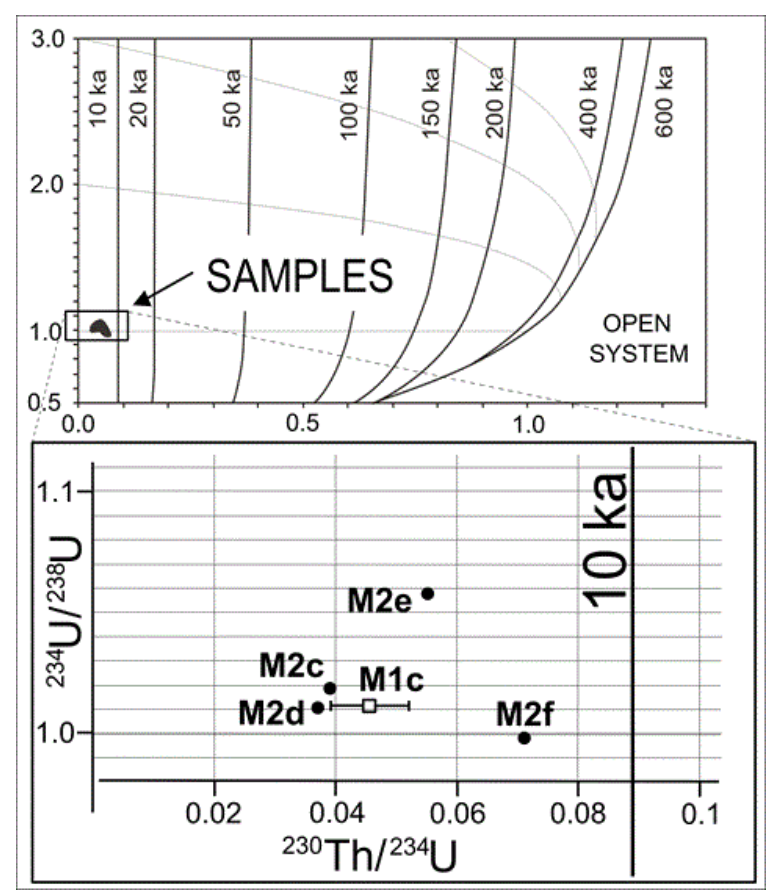

Figure 7: $234 \mathrm{U} / 238 \mathrm{U}$ vs. $230 \mathrm{Th} / 234 \mathrm{U}$ diagram.

\section{Climatic interpretation}

To determine the causes of isotopic variations in cave accretions is critical to understand the hydrological features influencing the fractionation from precipitation to dripping water [25]. Moreover, while dealing with tufas also biological accretion processes must be considered. During warm-dry half-years, dripping was rarely observed inside the Mannute Piccola. During cold-wet half-years water drips inside the cave fast after rains and then quickly decreases till usually vanishing in a few days. Furthermore, the catchment basin has very small size $\left(1 \mathrm{~km}^{2}\right)$. All these processes suggest lacking of chemical interaction between bedrock and infiltrated rainwater. Under the present weather conditions, also the soil cover should have a small influence on the isotope composition of the Mannute water dripping. Being the time of infiltration short, a significant component of atmospheric $\mathrm{CO}_{2}$ is retained in solution. Over the long term, evaporation processes could however slightly vary the oxygen isotopic composition [24]. As regards the contribution to the isotopic composition of photosynthetic fractionations, the present state of knowledge does not allow careful evaluations. The mechanism of photoreduction differs between plants and cyanobacteria and results in various fractionation patterns [44]. Researches on the effects in the isotopic composition of calcareous tufas need therefore to adopt new interdisciplinary approaches. Pending the resolution of uncertainties, the $\delta^{18}$ Os values of the collected samples (Table 2) should mainly reflect: (1) the $\delta^{18} \mathrm{Odw}$ values of the drip water that should approximate the $\delta^{18} \mathrm{Or}$ values of rainwater; (2) the cave temperature under which carbonates were formed [45]. Consequently, if the BSs grew in twilight conditions and the large entrance of the Mannute Piccola (see Figure 2) was not yet formed, $\delta^{18}$ Os has to be strictly determined by $\delta^{18}$ Or. The values of $\delta^{18}$ Os (Table 2) considerably differ from the present $\delta^{18} \operatorname{Or}[22,31]$ and thus both the possible function of "thermal flywheel" of the cave and the isotopes fractionations must be deeply investigated to extract real climate data from tufas. The carbon isotopes ratio $\left(\delta^{13} \mathrm{C}\right)$ of the hypogean carbonate accretions may depend on various control factors and also their selection needs an accurate overview of the site features [23]. Over the long term, shift of ${ }^{13} \mathrm{C}$ is climate-driven as a consequence of the change in interactions between soil and plants assemblage [25] preferably due to variation of the types of vegetation [46]. Differences in the photosynthetic pathway between vegetation types determine change in the ${ }^{13} \mathrm{C}$ production $[47,48]$. Enrichments in ${ }^{13} \mathrm{C}$ may reflect increases in the contribution of $\mathrm{C} 4$ plants (succulent, cacti, dry-climate grass) to the soil $\mathrm{CO}_{2}$ and / or reductions in the contribution of $\mathrm{C} 3$ plants (trees, temperate grass). Note that photosynthesis activity of the biological community living on bulbs may had discriminated the carbon isotopes probably fixing ${ }^{12} \mathrm{C}$ in prevalence $[49,50]$. However, evaporation within the cave would have favoured higher $\delta^{13} \mathrm{C}$ [25]. Both the opposite effects of these processes should affect the $\delta^{13} \mathrm{Cs}$ values of the samples (Table 2). In spite of the uncertainties, the interlacement of geochemistry and geological data on accretions growth (see previous paragraph) suggest that the BS number 1 of the Mannute Piccola cave (Figures 2-4) have recorded a shift from a cold-wet climate to a warm-dry one. Notable appears the amplitude of the variations of both $\delta^{18}$ Os and $\delta^{13} \mathrm{Cs}$. As regards the former, changes in rainfall amount and / or storm trajectories may be the probable causes [51,52]. $\delta^{18} \mathrm{Os}$ and $\delta^{13} \mathrm{Cs}$ covariations reflect millennial- or centennial-scale climatic change and lower order oscillations may have escaped the sampling grid. The search for the answers to such questions will be the object of further researches but a working hypothesis may be proposed. Following the suggestion of a millennial-scale change (as the span between the samples M2f and M2d would suggest, see Figure 7) the forcing cause may be the mid-Holocene Climatic Transition [53]. Highly intriguing is the correlation with climatic data of the Alimini Piccolo Lake located about $40 \mathrm{~km}$ north of Mannute Bay. In the lake deposits, at $4.35 \mathrm{ka}$ De Rita and Magri [54] have found evidences of rapid change in vegetation unaffected by human activity and interpreted as due to decrease of winter precipitation. This local event is framed in a timetransgressive onset of deforestation that affected the central Mediterranean between $4.5 \mathrm{ka}$ and $3.9 \mathrm{ka}$ and is in good agreement with the environmental trend described by Desprat et al. [7]. In such a view, the improving of geological data of the Mannute Karst system will provide useful comparisons. It must be stressed that well documented proxies preserved in pool and barrage tufas have yet contributed to understand the Holocene climatic variability on semiarid and arid regions [55,56].

The cluster of BSs inside the Mannute Piccola cave (Figure 4) is suitable to verify or falsify the hypothesis here proposed by repeated testing analyses. Dealing with geological heritage, samplings have to diligently preserve the sedimentological facies of the accretions. Moreover the numerous caves located along the south-eastern coast of the Salento peninsula constitute, as a whole, a powerful geological archive of Late Quaternary climate data. Especially the Mannute Caves system is suitable for this goal because of the lack of isotopes fractionation in aquifer and soil. Researches aimed towards the construction of such an archive may improve our knowledge of the climatic changes over the central Mediterranean as well as set the modelling of forthcoming weather conditions. As concerns the proposed working hypothesis, two critical points must be emphasized. Delle Rose et al. [28] have advanced the hypothesis of the end of sciophiluos conditions as a consequence of the opening of the main entrance (Figure 2) driven, in turn, by rock falls of a portion of the 
costal cliff. The new data show that the end of tufa development was closely related to the formation of the popcorn-like crusts thus suggesting a further reduction of the cave dripping whose causes must be investigated. Petrological fabric may be studied according to the technique adopted by Freytet and Varrecchia [57] while detailed micro-stratigraphic sampling can be obtained by the method described by Frisia [58]. The second critical point regards the difficulty to obtain reliable radiometric data to accurately date the tufas. It makes the identification of the climatic event hard although qualified methodologies can address such an issue [19,59]. However, due to the type of accretions the use of techniques based on the stratigraphic constraint appears more appropriate than isochron methods [20].

\section{Acknowledgement}

Support from the project eartH2Observe funded by the European Union's Seventh Programme for Research, Technological Development, and Demonstration under grant agreement no. 603608 is gratefully acknowledged.

\section{References}

1. Giorgi F (2006) Climate change hot-spots. Geophys Res Lett 33: 08707.

2. Lionello P (2012) The Climate of the Mediterranean Region: From the Past to the Future.

3. Alessandrini A, De Felice M, Zeng N, Mariotti A, Pan Y et al. (2014) Robust assessment of the expansion and retreat of Mediterranean climate in the 21st century. Sci Rep 4: 7211.

4. Gao X, Pal JS, Giorgi F (2006) Projected changes in mean and extreme precipitation over the Mediterranean region from a high resolution double nested RCM simulation. Geophys Res Lett 33: 03706.

5. Hatzianastassiou N, Papadimas CD, Lolis CJ, Bartzokas A, Levizzani V, et al. (2016) Spatial and temporal variability of precipitation over the Mediterranean Basin based on 32-year satellite Global Precipitation Climatology Project data. Part II: Inter-annual variability and trends. Int J Climatol 35: 4665.

6. Vautard R, Yiou P, D’Andrea F, de Noblet N, Viovy N, et al. (2007) Summertime European heat and drought waves induced by wintertime Mediterranean rainfall deficit. Geophys Res Lett 34: 07711.

7. Desprat S, Combourieu-Nebout N, Essallami L, Sicre MA, Dormoy I, et al. (2013) Deglacial and Holocene vegetation and climatic changes in the southern Central Mediterranean from a direct land-sea correlation. Clim Past 9: 767-787.

8. Kohfeld KE, Harrison SP (2000) How well can we simulate past climates? Evaluating the models using global palaeo-environmental datasets. Quaternary Sci Rev 19: 321-346.

9. Somot S, Sevault F, Déqué M, Crépon M (2008) 21st century climate change scenario for the Mediterranean using a coupled atmosphereocean regional climate model. Global Planet Change 63: 112-126.

10. Roberts CN, Zanchetta G, Matthew DJ (2010) Oxygen isotopes as tracers of Mediterranean climate variability: An introduction. Global Planet Change 71: 135-140.

11. Sturm C, Zhang Q, Noone D (2010) An introduction to stable water isotopes in climate models: benefits of forward proxy modelling for paleoclimatology. Clim Past 6: 115-129.

12. Jasechko S, Lechler A, Pausata FSR, Fawcett PJ, Gleeson, et al. (2015) Late-glacial to late-Holocene shifts in global precipitation $\delta 18 \mathrm{O}$. Clim Past 11: 1375-1393.

13. Brown Bw (1974) Induction, Deduction, and Irrationality in Geologic Reasoning. Geology 2: 456.

14. Raab T, Frodemann R (2002) What is it like to be a geologist? A phenomenology of geology and its epistemological implications. Philosophy and Geography 5: 69-81.
15. Wenning CJ (2009) Scientific epistemology: How scientists know what they know. J Phys Tchr Educ Online 5: 3-15.

16. Braconnot P, Harrison SP, Kageyama M, Bartlein PJ, Masson-Delmotte V et al. (2012) Evaluation of climate models using paleoclimatic data. Nature Climate Change 2: 417-424.

17. Dee S, Emile-Geay J, Evans MN, Allam A, Steig EJ, et al. (2015) PRYSM: An open-source framework for PRoxY System Modeling, with applications to oxygen-isotope systems. J Adv Model Earth Syst 7: 1220-1247.

18. Schwarcz HP (1989) Uranium series dating of Quaternary deposits. Quat Int 1: 7-17.

19. Geyh MA (2001) Reflections on the $230 \mathrm{Th} / \mathrm{U}$ dating of dirty material. Geochronomoteria 20: 9-14.

20. Hellstrom J (2006) U-Th dating of speleothems with high initial 230Th using stratigraphic constraint. Quat Geochronol 1: 289-295.

21. Wanner H, Beer J, Bütikofer J, Crowley TJ, Cubasch U, et al. (2008) Midto Late Holocene climate change: an overview. Quat Sci Rev 27: 1791-1828.

22. Roberts CN, Jones MD, Benkaddour A, Eastwood WJ, Filippi ML, et al. (2008) Stable isotope records of Late Quaternary climate and hydrology from Mediterranean lakes: the ISOMED synthesis. Quaternary Sci Rev 27: 2426-2441.

23. Baker A, Bradley C (2008) Modern stalagmite $\delta 18 \mathrm{O}$ : Instrumental calibration and forward modelling. Global Plan Change 71: 201-206.

24. Fairchild IJ, Smith CL, Baker A, Fuller L, Spötl C, Mattey D, et al (2006) Modification and preservation of environmental signals in speleothems. Earth Sci Rev 75: 105-153.

25. McDermott F (2004) Palaeo-climate reconstruction from stable isotope variations in speleothems: a review. Quaternary Sci Rev 23: 901-918.

26. Ford TD, Pedley HM (1996) A review of tufa and travertine deposits of the world. Earth Sci Rev 41: 117-175.

27. Taboroši D, Hirakawa K, Sawagaki T (2005) Carbonate precipitation along a microclimatic gradient in a Thailand cave-continuum of calcareous tufa and speleothems. J Cave Karst Stud 67: 69-87.

28. Delle Rose M, Desideri D, Patianna M, Posi ME, Renzulli A, et al. (2014) Carbonate Accretion Processes, Conservation and Enjoyment of the 'Mannute Caves' Geoheritage Site (Salento, Southern Italy). Geoheritage 6: 257-269.

29. Kottek M, Grieser J, Beck C, Rudolf B, Rubel F (2006) World map of the Köppen-Geiger climate classification updated. Meteorol Zeitschrift 15: 259-263.

30. Peel MC, Finlayson BL, McMahon TA (2007) Updated world map of the Köppen-Geiger climate classification. Hydrol Earth Syst Sci 11: 1633-1644.

31. Longinelli A, Selmo E (2003) Isotopic composition of precipitation in Italy: a first overall map. J Hydrol 270: 75-88.

32. Viles HA, Goudie AS (1990) Tufas, travertines and allied carbonate deposits. Progr Phys Geography 14: 19-41.

33. Frisia S, Borsato A (2010) Karst In: Alonso-Zarza AM, Tanner LH (eds), Carbonates in Continental Settings. Developments in Sedimentology 61: 269-318.

34. Delle Rose M, Cacciatore G, Patianna M (2007) The carbonate accretions of the Mannute Caves (Salento, southern Italy) and their paleoenvironmental significances. Epitome 2: 287.

35. Fornós JJ, Gelabert B, Ginés A, Ginés J, Tuccimei P, et al. (2002) Phreatic overgrowths on speleothems: a useful tool in structural geology in littoral karstic landscape. The example of eastern Mallorca (Balearic Islands). Geodin Acta 15: 133-125.

36. Pentecost A (1995) Quaternary travertine deposits of Europe and Asia Minor. Quaternary Sci Rev 14: 1005-1028.

37. Goudie AS, Viles HA, Pentecost A (1993) The Late Holocene tufa decline in Europe. The Holocene 3: 181-186.

38. Pentecost A, Riding $R$ (1986) Calcification in cyanobacteria. In: Leadbeater BSC, Riding R (eds) Biomineralization in lower plants and animals. Syst Assoc Spec, 30. 
Citation: Delle Rose M (2016) Changes in Holocene Precipitation Pattern of the Central Mediterranean Inferred from Hypogean Tufa Proxy Data. J Climatol Weather Forecasting 4: 158. doi:10.4172/2332-2594.1000158

Page 8 of 8

39. Brasier AT, Rogerson MR, Mercedes-Martin R, Vonhof HB, Reijmer JJG (2015) A test of the biogenicity criteria established for microfossils and stromatolites on Quaternary tufa and speleothem materials formed in the "twilight zone" at Caerwys. UK. Astrobiology 15: 883-900.

40. Martini J (1986) The trays: an example of evaporation-controlled speleothems. Bulletin of the South African Speleological Association 27: 46-51.

41. Ivanovich M, Harmon RS (1992) Uranium series disequilibrium. Applications to earth, marine and environmental sciences. Oxford Sci Publications, New York.

42. Szabo BJ, Rosholt JN (1982) Surficial continental sediments. In Ivanovich $\mathrm{M}$ and Harmon RS, (eds) Uranium series disequilibrium: applications to environmental problems. Oxford Sci Publications 246-267.

43. Hill CA (1986) The origin of "trays" (flat-bottomed popcorn) in Carlsbad Cavern. Cave Research Foundation Annual Report 14-16.

44. Helman Y, Barkan E, Eisenstadt D, Luz B, Kaplan A (2005) Fractionation of the three stable oxygen isotopes by oxygen-producing and oxygenconsuming reactions in photosynthetic organisms. Plant Physiol 138: 2292-2298.

45. Lachniet MS (2009) Climatic and environmental controls on speleothem oxygen-isotope values. Quaternary Sci Rev 28: 412-432.

46. Bar-Matthews M, Ayalon A (2004) Speleothems as palaeoclimate indicators, a case study from Soreq cave located in the Eastern Mediterranean region, Israel. In: Battarbee RW, et al. (eds) Past Climate Variability through Europe and Africa, Kluwer Academic Publishers 363-391.

47. Cerling TE, Quade J, Solomon DK, Bowman JR (1991) On the carbon isotopic composition of soil carbon dioxide. Geochim Cosmochim Acta 55: 3403-3405.

48. Lambers H, Chapin III FS, Pons TL (2008) Photosynthesis, respiration, and long-distance transport. In Lambers $\mathrm{H}$ et al, Plant Physiological Ecology, Springer pp10-153.
49. Smith FA, Walker NA (1980) Photosynthesis by aquatic plants: effects of unstirred layers in relation to assimilation of $\mathrm{CO} 2$ and $\mathrm{HCO} 3-$ and to carbon isotopic discrimination. The New Phytologist 86: 245-259.

50. Keeley JE (1991) Carbon 13 / carbon 12 ratios in photosynthesis. In Magill FN (edn) Magill's Survey of Science. Life Science Series. Salem Press, Pasadena 330-336.

51. Dansgaard W (1964) Stable isotopes in precipitation. Tellus 16: 436-468.

52. Drysdale R, Zanchetta G, Hellstrom J, Mass R, Fallick A, et al. (2006) Late Holocene drought responsible for the collapse of Old World civilizations is recorded in an Italian cave flowstone. Geology 34: 101-104.

53. Roberts CN, Brayshaw D, Kuzucuoglu C, Perez R, Sadori L (2011) The mid-Holocene climatic transition in the Mediterranean: Causes and consequences. The Holocene 21: 3-13.

54. De Rita F, Magri D (2009) Holocene drought, deforestation and evergreen vegetation development in the central Mediterranean: a 5500 year record from Lago Alimini Piccolo, Apulia, southeast Italy. The Holocene 19: 295-306.

55. Andrews JE, Pedley M, Dennis PF (2000) Palaeoenvironmental records in Holocene Spanish tufas: a stable isotope approach in search of reliable climatic archives. Sedimentology 47: 961-978.

56. Cremaschi M, Zerboni A, Spötl C, Felletti F (2010) The calcareous tufa in the Tadrart Acacus Mt. (SW Fezzan, Libya) An early Holocene palaeocliamte archive in the central sahara. Palaeogeogr Palaeoclimatol Palaeoecol 287: 81-94.

57. Freytet P, Varrecchia EP (1999) Calcitic radial palisadic fabric in freshwater stromatolites: diagenetic and recrystallized feature or physicochemical sinter crust? Sed Geol 126: 97-102.

58. Frisia S (2015) Microstratigraphic logging of calcite fabrics in speleothems as tool for palaeoclimate studies. Int J Speleoleology 44: 1-16.

59. Geyh MA (2008) Selection of suitable data sets improves 230Th / U dates of dirty material. Geochronometria 30: 69-77. 